\title{
Proximate Analysis and Mineral Composition of Seaweeds of Manamelkudi Coast, Pudukkottai District, India
}

\author{
P. Radha* \\ Department of Biochemistry, Agricultural College and Research Institute, Tamil Nadu \\ Agricultural University, Kudumiyanmalai - 622 104, Pudukkottai, India \\ *Corresponding author
}

\begin{tabular}{|c|}
\hline Keywords \\
\hline $\begin{array}{l}\text { G. salicornia, } G \text {. } \\
\text { edulis, Nutritional } \\
\text { and mineral } \\
\text { composition }\end{array}$ \\
\hline Article Info \\
\hline $\begin{array}{l}\text { Accepted: } \\
17 \text { July } 2018 \\
\text { Available Online: } \\
10 \text { August } 2018\end{array}$ \\
\hline
\end{tabular}

\section{Introduction}

Increasing awareness among consumers about health promoting foods has aroused interest in food supplement research worldwide. In addition to food supplements, consumption of exotic foods with proven nutritional values has also been gaining prominence in several developed countries (Herrero et al., 2006). Seaweeds have been recorded in human diets at least from $600 \mathrm{BC}$. They have been used as
Manamelkudi, located along the Palk Strait of East coast of Tamil Nadu serve as treasure houses for valuable marine resources like sea grass and seaweeds. A study was undertaken at Agricultural College and Research Institute, Kudumiyanmalai during 2016-17 to evaluate the nutritional composition of the seaweeds in order to use them as potential food ingredients. Seaweed samples were collected from Manamelkudi village of Pudukkottai district at different time intervals i.e. March, July and November and were identified as Gracilaria salicornia and Gracilaria edulis at Botanical Survey of India, Coimbatore. The identified seaweeds were assessed for their nutritional and mineral composition using standard methods. G.edulis was rich in carbohydrate (86.58\%), protein (1.98\%), lipid $(0.86 \%)$ and fiber content $(1.49 \%)$ when compared to G. salicornia (carbohydrates: $76.18 \%$; protein: $1.86 \%$; lipid: $0.51 \%$; fibre: $1.41 \%$ ). The ash content was found to be higher in G. salicornia (19.2\%). The seaweeds G. salicornia and G.edulis contains fairly large amounts of $\mathrm{N}(0.29$ and $0.32 \mathrm{mg} / 100 \mathrm{~g}), \mathrm{P}(15.10$ and $5.90 \mathrm{mg} / 100 \mathrm{~g})$ and $\mathrm{K}(465.10$ and $307.80 \mathrm{mg} / 100 \mathrm{~g}$ ) respectively. Both seaweeds also contained reasonable amounts of micronutrients except $\mathrm{Cu}$ which was found below detectable limit. Heavy metals namely lead, chromium, cadmium, nickel and mercury were found below detectable level in both the sea weeds. Hence, it may be concluded from the present study that the seaweeds $G$. salicornia and G. edulis may be utilised as value-added products in human nutrition.

food, animal feeds, fertilizer and as sources of traditional medicine in many Asian civilizations since ancient times. This old tradition has attracted research toward seaweeds, resulting in a large number of epidemiological studies that show the health benefits linked to the consumption of seaweed (Cassolato et al., 2008). Harvested in pure seawater, seaweeds can be considered as nature's most complete and balanced nutrient food source. Seaweeds are excellent dietary 
sources of vitamins, proteins, carbohydrates, trace minerals and other bioactive compounds (Kumar et al., 2008). Seaweeds provide all essential minerals and vitamins along with good amount of dietary fibers as well as antioxidants. The mineral content of seaweeds is highly significant and is probably responsible for many health benefits (Mendis and Kim, 2011). Many reports suggest that seaweeds are quite rich in various types of micro and macro nutrient such as calcium, sodium, magnesium, iron etc. (Dawczynski et al., 2007). Many macroalgal species have been used as ingredients in both medicinal and food preparations, traditionally, in different regions across the world (Chandini et al., 2008). Being rich in minerals, vitamins, trace elements and bioactive potential substances, seaweeds are called medical food of the $21^{\text {st }}$ century (Khan and Satam, 2003). The objective of the present study was to evaluate the proximate and mineral composition of seaweeds collected from Manamelkudi coast of Pudukkottai district.

\section{Materials and Methods}

\section{Collection of seaweeds}

The seaweeds were collected from Manamelkudi coast of Pudukkottai district and were identified at Botanical Survey of India, Coimbatore. The identified seaweeds are Gracilaria salicornia (C.Agardh) Dawson and Gracilaria edulis (S.G. Gmel.) P.C. Silva Gracilariaceae. The samples were washed in sea and fresh water to remove salt, associated organisms and other extraneous matters.

Then the seaweeds were spread on blotting paper to remove excess water, then air dried and powdered. The powdered samples were then stored in refrigerator and used for the estimation of nutritional parameters namely carbohydrates, protein, lipid, fibre and ash content and minerals.

\section{Proximate analysis}

The parameters determined for proximate analysis include total carbohydrates, proteins, lipids, fiber and ash content.

\section{Carbohydrate}

The total carbohydrate was estimated by following the Phenol sulphuric acid method of Dubois et al., (1956).

\section{Protein}

Total protein was estimated by the method of Lowry et al., (1951).

\section{Lipid}

Lipids were estimated by the Folch et al., (1957) method.

\section{Fiber}

The content of dietary fiber in seaweeds was determined according to the AOAC enzymatic gravimetric method (AOAC official methods of Analysis, 2005).

\section{Ash content}

The ash content of the seaweeds was determined by incinerating $1 \mathrm{~g}$ of the sample taken in a silica crucible and kept in a muffle furnace at $600^{\circ} \mathrm{C}$. After incineration, the net content was cooled and weighed and expressed in terms of percentage.

\section{Determination of mineral element}

The seaweed (2g) was taken in a glass container and $10 \mathrm{ml}$ of perchloric acid was added to it and left without disturbance for 5 min (to remove the organic constituents present in it). Then, $10 \mathrm{ml}$ of concentrated nitric acid was added to it and incubated for 5 
min and then added with $10 \mathrm{ml}$ of $\mathrm{HCl}$. The mixture was allowed to evaporate and the final residue was dissolved in $10 \mathrm{ml}$ of concentrated $\mathrm{HCl}$. The filtrate was subjected to analysis in atomic absorption spectrophotometer. The minerals analyzed were potassium, manganese, iron, copper, zinc, lead, chromium, cadmium, nickel and mercury. Total nitrogen was estimated by Microkjeldhal method (Humphries, 1956) and phosphorus by Fiske and Subbarow (1925) method.

\section{Statistical Analysis}

All the analyses were performed in triplicates and the results were statistically analyzed and expressed as mean $(n=3) \pm$ standard deviation (SD).

\section{Results and Discussion}

Findings have shown that the nutritional composition of seaweeds varies with species, geographic area, season of the year and temperature of water, by which seaweeds can presumably be signalled to stimulate or inhibit the biosynthesis of different component nutrients. Despite these variations in nutritional components, reports on certain edible seaweeds show that many of them still contain significant amounts of protein, vitamins and minerals essential for human nutrition.

Seaweeds have been identified and grouped in three different classes, including brown algae (Phaeophyta), red algae (Rhodophyta) and green algae (Chlorophyta).

In the case of red seaweeds there are five major edible genera, including Porphyra, Palmaria, Gracilaria, Gelidium and Kappaphycus (Eucheuma). In particular, numerous red seaweeds of the genus Gracilaria are utilised as fresh food in many parts of the world.
In the present investigation an attempt was made for proximate composition and mineral content of Gracilaria salicornia and Gracilaria edulis to provide a good estimation in order to evaluate their potential use as food ingredients.

\section{Proximate composition}

The proximate composition including carbohydrate, protein, lipid, fiber and ash content was determined (Table 1).

Carbohydrate is one of the important components for metabolism and it supplies the energy needed for respiration and other most important processes (Gokulakrishnan et al., 2015). The concentration of carbohydrate was higher in Gracilaria edulis (86.58 $\pm 2.03 \%)$ than Gracilaria salicornia (76.18 $\pm 0.4 \%)$. Proximate composition analysis of macroalgae has reported carbohydrates as the most abundant component (Omer et al., 2013) constituting up to $90.83 \%$ of the dry matter of the seaweeds.

Proteins have crucial functions in all the biological processes. Their activities can be described by enzymatic catalysis, transport and storage, mechanical sustentation control. The mean protein content in Gracilaria edulis was found to be $1.98 \pm 0.01 \%$ and $1.86 \pm$ $0.21 \%$ in Gracilaria salicornia. The crude protein content of Gracilaria salicornia from Mkomani is found to be $7.86 \pm 0.03 \%$ which is similar to that of the protein content in most Gracilaria species which ranges from 7-13\% (Briggs and Smith, 1999). Variations in the protein content of seaweeds can be due to factors such as species, seasons and geographic area (Fleurence 1999, SánchezMachado et al., 2004)

In general, the lipid provides very much level of energy in oxidation process than other biological compounds. They comprise as a 
storage material for living organisms. In macro algae lipids are widely spread worldwide (Miller, 1962). In the present study 0.86 $\pm 0.07 \%$ and $0.51 \pm 0.04 \%$ of lipid was recorded in Gracilaria edulis and Gracilaria salicornia respectively. The crude fat content of most seaweed species was generally less than $3.0 \%$ which was comparable to previous studies (Polat and Ozugal, 2008; Marsham et al., 2007).

Dietary fibers promote beneficial physiological effects including laxation and blood cholesterol regulation. Dietary fibers can bind toxic compounds and thus eliminate their mobility in the organism of the consumer. In the present investigation, $G$. edulis recorded higher fiber content (1.49 \pm $0.17 \%$ ) when compared to $G$. salicornia (1.41 $\pm 0.20 \%$ ). The results are in accordance with the reports of Tabarsa et al., (2012) and Sakthivel and Pandima Devi (2015). Ash content in seaweeds is generally high and the essential minerals and trace elements needed for human nutrition are present in seaweeds.

These wide ranges of minerals are usually not found in edible land plants. Mineral content in seaweeds vary with species, geographical origin, season, environment and processing of seaweeds. Seaweeds usually contain $\sim 20 \%$ ash content which is quiet high compared to most vegetables (Sanchez-Machado et al., 2004), in which ash value falls within the range of 5$10 \%$. In this investigation ash content in Gracilaria salicornia $(19.2 \pm 0.72 \%)$ recorded higher than ash content in Gracilaria edulis $(7.83 \pm 0.06 \%)$.

Plate.1 Gracilaria salicornia
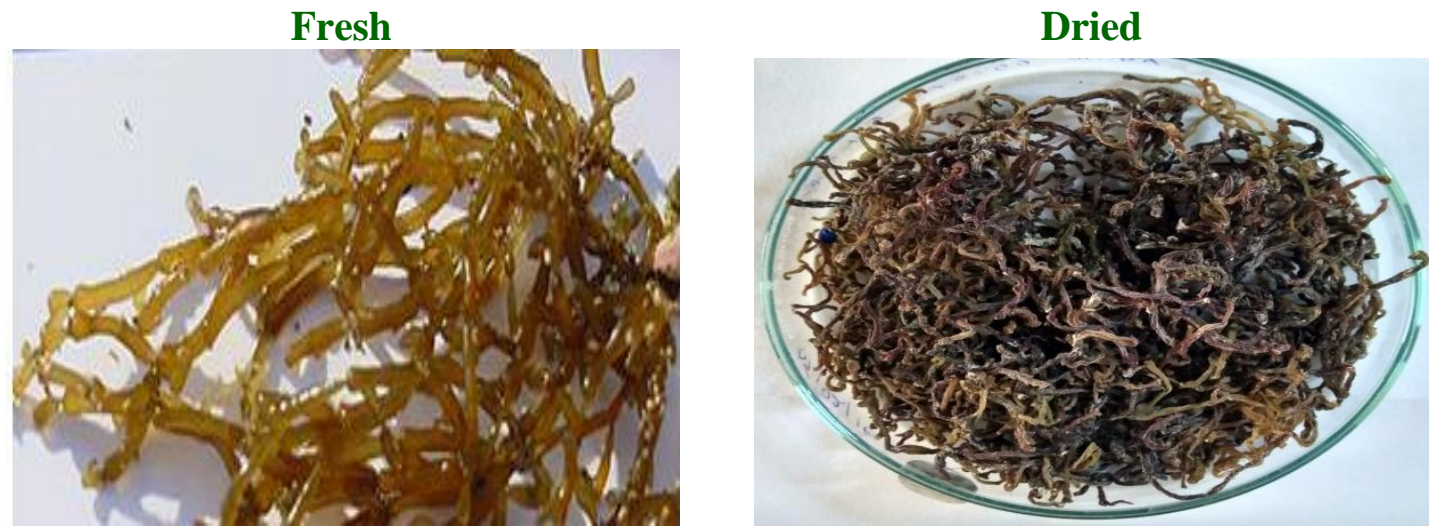

Plate.2 Gracilaria edulis
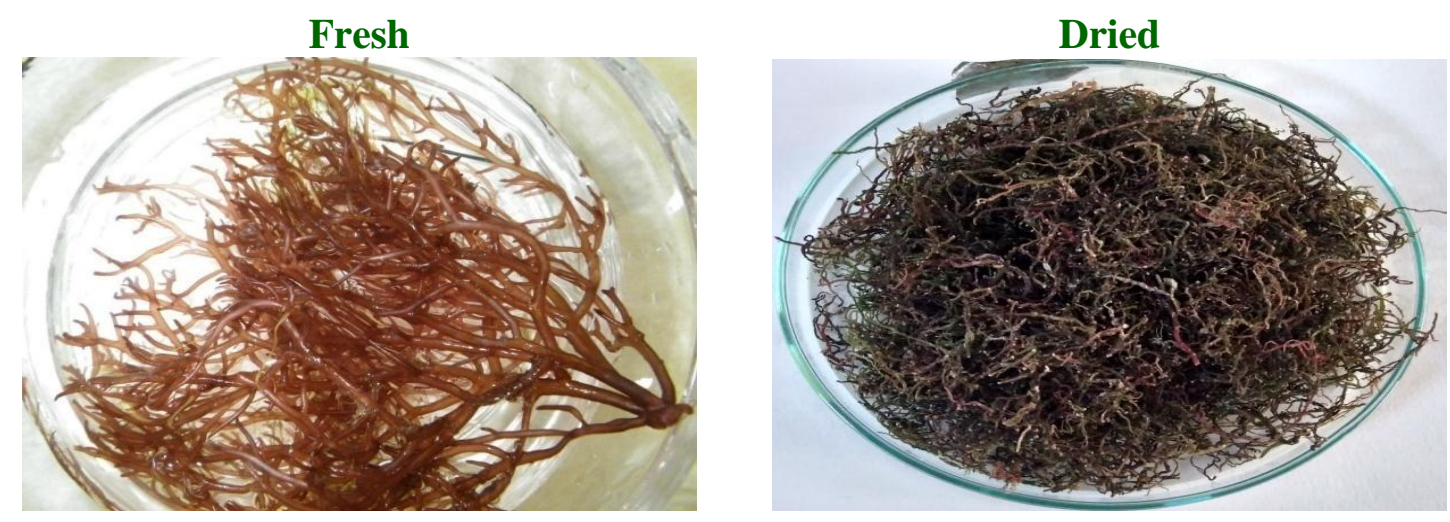
Table.1 Proximate composition of Gracilaria salicornia and Gracilaria edulis

\begin{tabular}{|l|c|c|}
\hline \multicolumn{1}{|c|}{ Proximate composition $(\mathrm{g} / \mathbf{1 0 0 g})$} & Gracilaria salicornia & Gracilaria edulis \\
\hline Carbohydrate & $76.18 \pm 0.40$ & $86.58 \pm 2.03$ \\
\hline Protein & $1.86 \pm 0.21$ & $1.98 \pm 0.01$ \\
\hline Lipid & $0.51 \pm 0.04$ & $0.86 \pm 0.07$ \\
\hline Fiber & $1.41 \pm 0.20$ & $1.49 \pm 0.17$ \\
\hline Ash & $19.2 \pm 0.72$ & $7.83 \pm 0.06$ \\
\hline
\end{tabular}

Values are expressed by mean \pm SD of triplicates

Table.2 Concentration of macronutrients in Gracilaria salicornia and Gracilaria edulis

\begin{tabular}{|l|c|c|}
\hline Mineral composition $(\mathrm{g} / \mathbf{1 0 0 g})$ & Gracilaria salicornia & Gracilaria edulis \\
\hline Nitrogen & 0.29 & 0.32 \\
\hline Phosphorus & 15.10 & 5.90 \\
\hline Potassium & 465.10 & 307.80 \\
\hline
\end{tabular}

Table.3 Concentration of micronutrients in Gracilaria salicornia and Gracilaria edulis

\begin{tabular}{|l|c|c|}
\hline \multicolumn{1}{|c|}{ Mineral composition $(\mathrm{g} / \mathbf{1 0 0 g})$} & Gracilaria salicornia & Gracilaria edulis \\
\hline Manganese & 0.03 & 0.01 \\
\hline Iron & 1.7 & 0.5 \\
\hline Copper & BDL & BDL \\
\hline Zinc & 0.01 & 0.01 \\
\hline Lead & BDL & BDL \\
\hline Chromium & BDL & BDL \\
\hline Cadmium & BDL & BDL \\
\hline Nickel & BDL & BDL \\
\hline Mercury & BDL & BDL \\
\hline
\end{tabular}

BDL - Below Detectable Limit

\section{Nutrient analysis}

Seaweeds are considered as very good source of minerals. Important minerals accumulate in seaweeds at much higher levels than in many well-known terrestrial sources of minerals such as meat and spinach. Even a small proportion of daily intake of seaweeds $(\sim 25 \mathrm{~g})$ fulfils the minerals requirement of an adult human as recommended by Dietary Reference Intake (DRI), 2000. Seaweeds are an excellent nutrient source, containing high amounts of macro and micronutrients.
Among the macro minerals, potassium (465.10 and $307.80 \mathrm{mg} / 100 \mathrm{~g}$ ) was the most abundant element, followed by phosphorus $(15.10$ and $5.90 \mathrm{mg} / 100 \mathrm{~g})$ and nitrogen $(0.29$ and $0.32 \mathrm{mg} / 100 \mathrm{~g}$ ) in the two seaweeds Gracilaria salicornia and Gracilaria edulis studied respectively (Table 2). A similar trend was reported by other authors (Chan and Matanjun, 2017; Matanjun et al., 2009; Li, 2009), who found that $K$ was the main mineral element. In biological systems, heavy metals have been reported to affect cellular organelles and components such as cell 
membrane, mitochondrial, lysosome, endoplasmic reticulum, nuclei, and some enzymes involved in metabolism, detoxification, and damage repair (Wang and Shi, 2001). Metal ions have been found to interact with cell components such as DNA and nuclear proteins, causing DNA damage and conformational changes that may lead to cell cycle modulation, carcinogenesis or apoptosis (Beyersmann and Hartwig, 2008). Reactive oxygen species (ROS) production and oxidative stress play a key role in the toxicity and carcinogenicity of metals (Yedjou and Tchounwou, 2006).

Heavy metals are harmful to human health. Lead, for instance, has carcinogenic properties, and it impairs both the respiratory and digestive systems and suppresses the immune system; this metal is particularly harmful in children, damaging their intelligence and nervous systems (Preuss, 1993).

Cadmium accumulates easily in the circulatory system, kidney (especially the renal cortex), lung, and heart, and is toxic to bones and gonads (Rezende et al., 2011). Chromium is harmful to the skin, liver, kidney, and respiratory organs, causing various diseases, such as dermatitis, renal tubular necrosis, perforation of the nasal septum, and lung cancer (Gad, 1989). Excessive copper intake can cause nausea, vomiting, kidney failure, blood cell damage, and central nervous system inhibition. Nickel is primarily accumulated in the spinal cord, brain, and organs due to its mutability and carcinogenicity (Hashem et al., 2011).

The results showed that Gracilaria salicornia and Gracilaria edulis contains reasonable amounts of micronutrients namely $\mathrm{Mn}, \mathrm{Fe}$ and $\mathrm{Zn}$ and no detectable levels of copper, lead, chromium, cadmium, nickel and mercury (Table 3).
Although concerns have been raised regarding the accumulation of heavy metals in humans, toxicological investigations have extensively showed that most of the heavy metals (As, $\mathrm{Cd}, \mathrm{Cu}, \mathrm{Hg}, \mathrm{Pb}, \mathrm{Zn}$ ) in algal biomass are generally below the toxic limits allowed in several countries (Indegaard and Minsaas, 1991). The results of the current study is in agreement with the study of Tabarsa et al., (2012) who reported that G. salicornia and $U$. lactuca had any detectable amounts of $\mathrm{Cd}, \mathrm{Zn}$ and $\mathrm{Pb}$.

The seaweeds Gracilaria salicornia and Gracilaria edulis exhibited high carbohydrate and ash contents, appreciable quantities of protein and crude fibre as well as low total lipid. It was shown that both the seaweeds contain relatively high levels of macrominerals and reasonable levels of micronutrients analysed except copper and heavy metals which was found below detectable levels. These two edible seaweeds exhibited a broad spectrum of nutritional compositions which make them excellent candidates for a healthy food for human nutrition.

\section{Acknowledgement}

The author acknowledges her thanks to Tamil Nadu Agricultural University, for approving and to carry out this University Research Project at Agricultural College and Research Institute, Kudumiyanmalai, Pudukkottai.

\section{References}

AOAC. Official methods of analysis of the AOAC International. $18^{\text {th }}$ ed. Association of official analytical chemists. Arlington, VA, USA, Washington. 2005.

Beyersmann, D. and Hartwig, A. 2008. Carcinogenic metal compounds: recent insight into molecular and cellular 
mechanisms. Arch Toxicol. 82(8): 493512.

Briggs, M. R. P. and Smith, S. J. F. 1993. Macroalgae in aquaculture: An overview and their possible roles inshrimpculture, Proceedings of a Conference on Marine Biotechnology in the Asia Pacific. Bangkok, Thailand. pp. 137-143.

Cassolato, J.E.F., Noseda, M.D., Pujol, C.A., Pellizzari, F.M., Damonte, E.B. and Duarte, M.E.R. 2008. Chemical structure and antiviral activity of the sulfated heterorhamnan isolated from the green seaweed Gayralia oxysperma. Carbohydr Res. 343: 3085-3095.

Chan, P.T. and Matanjun, P. 2017. Chemical composition and physicochemical properties of tropical red seaweed, Gracilaria changii. Food Chem. 221: 302-310.

Chandini, S.K, Ganesan, P. and Suresh, P.V. 2008. Seaweeds as source of nutritionally beneficialcompoundsreview. Journal of Food Science and Technology. 45 (1): 1-13.

Dawczynski, C., Schafer, U., Leiterer, M. and Jahreis, G. 2007. Nutritional and toxicological importance of macro, trace and ultra-trace elements in algal food products. J. Agric. Food Chem. 55: 10470-10475.

Dubois, M., Gilles, K.A., Hamilton, J.K., Rebers, P.A. and Smith, F., 1956. Colorimetric method for determination of sugars and related substances. Anal. Chem. 28: 350-356.

Fiske, C.J and Subarrow, Y. 1925. The colorimetric determination of phosphorus. J Biol Chem 1925, 66: 375-400.

Fleurenc, J. 1999. Seaweed proteins: biochemical, nutritional aspects and potential uses. Trends Food Sci Technol., 10: 25-28.
Folch, J., Lees, M., and Stanley G H.S. 1957. A simple method for the isolation and purification of total lipids from animal tissues. J. Biol Chem, 226: 497-509.

Gad, S.C. 1989. Acute and chronic systemic chromium toxicity. Sci Total Environ., 86: 149-157

Gokulakrishnan, S., Raja, K., Sattanathan, G. and Subramania, J. 2015. Proximate composition of Bio Potential Seaweeds from Mandapam, South East Coast of India, International Letters of Natural Sciences, 45: 49-55.

Hashem, E.Y., Seleim, M.M. and El-Zohry, A.M. 2011. Environmental method for spectrophotometric determination of copper (II). Green Chem Lett Rev, 4: 241-248

Herrero, M., Cifuentes A. and Ibanez, E. 2006. Sub- and super-critical fluid extraction of functional ingredients from different natural sources: plants, food-by-products, algae and microalgae - a review. Food Chem. 98: $136-148$

Humphries, C.E. 1956. Modern methods of plant analysis. p. 487.

Indegaard, M. and Minsaas, J. 1991. Animal and human nutrition, in Seaweed Resources in Europe. Uses and Potential, ed. by Guiry $\mathrm{M}$ and Blunden G. John Wiley \& Sons, New York, pp. 21-64.

Khan, S.I. and Satam, S.B. 2003. Seaweed Mariculture: Scope and Potential in India. Aquaculture-Asia, VIII: 4: 26-29

Kumar, C.S., Ganesan, P., Suresh, P.V. and Bhaskar, N. 2008. Seaweeds as a source of nutritionally beneficial compoundsA review. J Food Sci Technol. 45:1-13

Li, B.F. 2009. Marine Health Food; Chemical Industry Press: Beijing, China, pp. 5172.

Lowry, O.H., Rosebrough, N.J., Farr, A.L. and Randall, R.J. 1951. Protein 
measurement with the folin phenol reagent. J. Biol Chem, 193: 265-273.

Marsham, S., Scott, G.W. and Tobin, M.L. 2007. Comparison of nutritive chemistry of a range of temperate seaweeds. Food Chem., 100: 13311336.

Matanjun, P., Mohamed, S., Mustapha, N.M. and Muhammad, K. 2009. Nutrient content of tropical edible seaweeds, Eucheuma cottonii, Caulerpa lentillifera and Sargassum polycystum. Journal of Applied Phycology, 21: 7580.

Mendis, E. and Kim, S.K. 2011. Present and future prospects of seaweeds in developimg functional foods. Adv. Food Nutr. Res. 64: 1-15.

Miller, J.P.A. 1962. Fats Steroids. In: Physiology and Biochemistry of Algae. Lewin RA (Ed.), Academic Press, New York. Pp. 92.

Omer, H.H., Abdullatif, B.M., Al-Kazan, M.M. and Adel, M.E. 2013. Red Sea water and biochemical composition of seaweeds at southern coast of Jeddah, Saudi Arabia. Life Science Journal. 10 (4).

Polat, S. and Ozogul, Y. 2008. Biochemical composition of some red and brown macroalgae from the northeastern Mediterranean Sea. Int. J. Food Sci. Nutr. 59: 566-572.

Preuss, H.G. 1993. A review of persistent, low-grade lead challenge: neurological and cardiovascular consequences $\mathrm{J}$ Am Coll Nutr, pp. 246-254
Rezende, H.C., Nascentes, C.C. and Coelho, N.M.M. 2011. Cloud point extraction for determination of cadmium in soft drinks by thermospray flame furnace atomic absorption spectrometry Microchem J, 97 (2011), pp. 118-121

Sakthivel, R. and Pandima Devi, K. 2015. Evaluation of physicochemical properties, proximate and nutritional composition of Gracilaria edulis collected from Palk Bay. Food Chem. 174: 68-74

Sanchez-Machado, D.I., Lopez-Cervantes, J., Lopez-Hernandez, J. and PaseiroLosada, P. 2004. Fatty acids, total lipid, protein and ash contents of processed edible seaweeds. Food Chemistry, 85: 439-444.

Tabarsa, M., Rezaei, M., Ramezanpour, Z. and Waaland, J.R. 2012. Chemical compositions of the marine algae Gracilaria salicornia (Rhodophyta) and Ulva lactuca (Chlorophyta) as a potential food source. Journal of the Science of Food and Agriculture. 92(12): 2500-2506

Wang, S. and Shi, X. 2001. Molecular mechanisms of metal toxicity and carcinogenesis. Mol Cell Biochem. 222: 3-9.

Yedjou, C.G. and Tchounwou, P.B. 2006. Oxidative stress in human leukemia cells (HL-60), human liver carcinoma cells $\left(\mathrm{HepG}_{2}\right)$ and human Jerkat-T cells exposed to arsenic trioxide. Metal Ions Biol Med. 9: 298-303.

\section{How to cite this article:}

Radha, P. 2018. Proximate Analysis and Mineral Composition of Seaweeds of Manamelkudi Coast, Pudukkottai District, India. Int.J.Curr.Microbiol.App.Sci. 7(08): 3121-3128. doi: https://doi.org/10.20546/ijcmas.2018.708.333 